\title{
ОСВОЕНИЕ ОБУЧАЮЩИМИСЯ ТЕМАТИЧЕСКИХ РАЗДЕЛОВ МОРАЛЬНОЙ ФИЛОСОФИИ В РАМКАХ КУРСА «ПСИХОЛОГИЯ ВОСПИТАНИЯ»
}

\author{
Суслова И.Б.
}

Международный инновационный университет, г. Сочи, Краснодарский край, Российская Федерация

Статья содержит блок вопросов, разработанный автором в рамках курса «Психология воспитания», относящийся к области этики и моральной философии. Данные вопросы, являясь частью практических занятий, преследуют иель активизировать в сознании студентов духовно-нравственную компоненту. В результате ознакомления студентов с последующими разделами, бесед и прослушивания тематического ицикла ожидается усиление мотивации студентов к личностной самоактуализации, самопознанию, присвоению иенностных парадигм этики и философии морали.

Ключевые слова: моральная философия; нравственный долг; моральная культура; мотивация к самопознанию; самоактуализацчия; духовно-нравственное развитие.

\section{MASTERING BY STUDENTS OF THEMATIC SECTIONS OF MORAL PHILOSOPHY AS PART OF THE COURSE "PSYCHOLOGY OF EDUCATION"}

\author{
Suslova I.B. \\ International Innovation University, Sochi, Krasnodar region, \\ Russian Federation
}

The article contains a block of questions developed by the author as part of the course "Psychology of Education", relating to the field of ethics and moral philosophy. These questions, being part of the practical classes, 
are aimed at activating the spiritual and moral component in the students' minds. As a result of familiarization of students with the subsequent sections, conversations and listening to the thematic cycle, is expected an increase in students 'motivation for personal self-actualization, self-knowledge, appropriation of value paradigms of ethics and moral philosophy.

Keywords: moral philosophy; moral duty; moral culture; motivation for self-knowledge; self-actualization; spiritual and moral development.

Для психологии воспитания неоспоримым является следующий постулат: только благодаря пробуждению в личности ее нравственных оснований, расширению границ ее духовного «Я», личность наполняется чувством своей подлинной человеческой ценности, высоким чувством сопричастности всеобщему. «Человек только благодаря этому полагает, что ощущает свою личную ценность, в сравнении с которой ценность приятного или неприятного состояния совершенно ничтожна», - писал создатель «нравственной Библии» Иммануил Кант [2, с. 292]. Возвышая нравственное достоинство личности, мы, тем самым, придаем особую этическую ценность образовательной деятельности, наполняем образовательное пространство нравственно ценностным содержанием, создаем атмосферу, максимально способствующую духовному самоотождествлению и личностной самоактуализации студентов.

С целью актуализации в сознании обучающихся морально-нравственных категорий и ценностей нами была разработана анкета, содержащая отсылки к моральной философии И. Канта, идеи которой были использованы нами ранее при разработке концепции психолого-педагогического сопровождения процесса духовно-нравственного самовоспитания студентов вуза. Материалом исследования послужила монография автора «педагогическая антропология Иммануила Канта - современные проекции», методы исследования: анализ и синтез, восхождение от абстрактного к конкретному, сравнение, аналогия, метод систематизации и обобщения психолого-педагогических материалов, источников и научной литературы. Обучающимся были адресованы следующие вопросы: 
1. Можно ли утверждать, что человек, уважающий моральный закон, обладает нравственной культурой?

2. Согласны ли Вы с изречением: «Именно добровольное, осознанное подчинение моральному закону отличает человека от других разумных существ»? Обоснуйте свою точку зрения.

3. Заложено ли в нас изначально, «доопытно» («apriori») понятие о моральном долге? Относится ли это понятие к категории «врожденных идей»?

- По мнению И. Канта, понятие морального долга относится к трансцендентальной апперцепции нашего разума, следовательно, является «доопытной», врожденной идеей.

4. Могут ли под чувство долга маскироваться эгоистичные посылы и устремления нашего низшего «я» или ««alterego»? Приведите свои рассуждения.

5. Как Вы понимаете принцип уважения личности к моральному закону, выраженный следующими словами И. Канта: «Сознание свободного подчинения воли закону, связанного, однако, с неизбежным принуждением по отношению ко всем склонностям, но лишь со стороны собственного разума, и есть это уважение к закону» [3, с. 248].

6. В данной формулировке соседствуют, на первый взгляд, несовместимые понятия: «свобода» и «принуждение», «подчинение». Как Вы понимаете тезис «самопринуждение по отношению ко всем склонностям» как условие сводного и осознанного подчинения воли моральному закону? Проиллюстрируйте Ваше рассуждение примерами.

7. Сохранять свою жизнь, с точки зрения И. Канта, есть долг. Однако, чем, на Ваш взгляд, отличается «трусливая заботливость» о своей жизни от сохранения жизни «из чувства долга»? Приведите примеры.

8. Как Вы понимаете долг «оказания благодеяний»? Всякое ли благодеяние или добрый поступок обладает нравственной ценностью?

9. Согласны ли Вы с мыслью философа: обеспечение своего счастья также является нравственным долгом человека? Приведите свои рассуждения. 
10. Что, по Вашему мнению, означает воля внутреннего благорасположения к людям? Является ли она нравственным долгом и нравственной ценностью?

11. Как Вы понимаете формулировку нравственного закона И. Канта: «поступай только согласно такой максиме (принципу - И.С.), руководствуясь которой ты в то же время можешь пожелать, чтобы она стала всеобщим законом» [3, с. 260].

12. Приведите свои рассуждения: почему человек не может пожелать, чтобы все безнаказанно давали бы ложные обещания, или не развивали свои таланты?

13. Почему нравственный закон или «категорический императив» может быть назван безусловным? (Сам философ поясняет, что он один «не основывается ни на каком интересе»).

14. На чем, согласно Вашему мнению, основывается необходимость поступать согласно этому принципу: на чувствах, побуждениях и склонностях или на принципах разумного взаимодействия между людьми?

15. Почему современному человеку необходим критический анализ своих поступков, их мотивов, своих склонностей и устремлений?

16. Согласны ли Вы с утверждением: наша самореализация (творческая, профессиональная, личностная) возможна лишь при условии моральности? Приведите свои рассуждения.

17. Как Вы понимаете идею И. Канта: «...значимость воли как всеобщего закона для возможных поступков имеет аналогию со всеобщей связью существования вещей по всеобщим законам природы» [2, с. 280]. (Философ имеет ввиду морально обусловленную волю отдельной личности).

18. Являются ли, на Ваш взгляд, экологические, экономические, политические проблемы современности следствием забвения моральнонравственных принципов и регулятивов? Обоснуйте свою точку зрения.

19. Как, на Ваш взгляд, сочетаются свободная воля субъектов с категоричностью нравственных устоев?

20. Как Вы понимаете изречение И. Канта: «Совсем не одно и то же сделать человека счастливым или же сделать его хорошим, сде- 
лать хорошего человека умным и понимающим свои выгоды или же сделать его добродетельным»? [2, с. 285].

21. Часто люди совершают нравственные поступки из страха наказания от природы, общества или Бога, либо - из-за желания собственного счастья. Обоснуйте, почему такие поступки не являются проявлением личностного достоинства человека?

22. Что дает основания И. Канту бесконечно возвышать личностное достоинство индивидуума?

23. Как Вы понимаете формулу И. Канта: 1) индивидуальная воля должна стать законодателем всеобщего; 2) другая личность должна являться для нас целью, а не средством? Как эти два постулаты связаны друг с другом?

24. Как бы Вы определили понятие «добродетель»?

25. И. Кант определял добродетель как твердость принципа («максимы», И. Кант) человека при соблюдении своего долга [3]. Согласны ли Вы с этой формулировкой? В чем, на Ваш взгляд, уникальность и оригинальность этого определения?

26. Нужно ли человеку, и в особенности, современному человеку, воспитывать свою нравственную культуру?

30. Немецкий мыслитель приравнивал нравственную культуру человека к его природной мудрости и полагал, что воспитание нравственной культуры есть «культивация совести» или же «культивация задатков доброй воли». Как Вы понимаете это определение?

31. Как Вы полагаете - необходимо ли личности осмыслить базовые этические категории, такие, как добродетель, нравственный долг, моральная ответственность и др. Обоснуйте свою точку зрения.

32. Одной из этических обязанностей человека перед самим собой И. Кант называл долг к самосовершенствованию. Как Вы считаете, стремление к материальному обогащению и получению удовольствий как к цели жизни противоречит указанной выше этической обязанности? Приведите аргументированные рассуждения.

33. Лишь осознание своей самоценности как субъекта нравственной воли может послужить основанием для личностной пере- 
ориентации, учил великий мыслитель. Согласны ли Вы с данным утверждением и почему?

34. Приведите свои рассуждения о высказывании И. Канта: «добродетельный не может утратить своей добродетели» [3, с. 341]. Как Вы считаете, коррелируется ли оно с известным библейским изречением: рука дающего не оскудеет?

35. Философ утверждает, что, делаясь «игрушкой одних лишь склонностей», человек становится вещью, парадоксально служа тем самым общественному прогрессу. Как Вы понимаете данное утверждение?

Мы убеждены, что этика Канта, и в частности, его теория обоснования морали, - это тот непреходящий, актуальный для каждого участника образовательного процесса, этико-философский ориентир, который не только открывает перед личностью новые горизонты духовного «Я» и рубежи самопознания, но и требует все более полного осмысления и активного присвоения его ценностных парадигм.

Результаты исследования обсуждались на внутривузовских конференциях и круглых столах, а также на заседаниях кафедры «Управления и гуманитарных наук» МИУ.

\section{Выводы}

Вследствие осмысления данного блока морально-этических категорий обучающиеся не только актуализируют нравственную сферу своего сознания, но и научатся рассуждать об этике и морали в теоретическом и практическом измерениях. Прослушивание курса психологии воспитания в совокупности с данными разработками способствует, согласно нашему убеждению, духовному развитию студентов, приросту их морально-нравственных качеств.

\section{Список литературы}

1. Берулава М.Н. Современная теоретическая платформа отечественного образования / М.Н. Берулава // Гуманизация образования. 2013. №4.

2. Кант И. Собрание сочинений в 8 томах. Т.4: Основоположения метафизики нравов. М.: ЧОРО. 1994. 
3. Кант И. Собрание сочинений в 8 томах. Т.6: Религия в пределах только разума. Метафизика нравов. М.: ЧОРО. 1994.

4. Максимова Н.Ю. Гуманизация образования как социокультурный процесс (философский аспект). Дис. ... канд. пед. наук. М. 2003.

5. Петровский А.В., Ярошевский М.Г. Основы теоретической психологии. М.: ИНФРА-М, 1998.

6. Суслова И.Б. Развитие духовной культуры личности средствами образования. Учебное пособие. Сочи. Изд-во «Оптима», 2019.

\section{References}

1. Berulava M.N. Sovremennaya teoreticheskaya platforma otechestvennogo obrazovaniya / M.N. Berulava // Gumanizatsiya obrazovaniya. 2013. №4.

2. Kant I. Sobranie sochineniy v 8 tomakh. T.4: Osnovopolozheniya metafiziki nravov. M.: ChORO. 1994.

3. Kant I. Sobranie sochineniy v 8 tomakh. T.6: Religiya v predelakh tol'ko razuma. Metafizika nravov. M.: ChORO. 1994.

4. Maksimova N.Yu. Gumanizatsiya obrazovaniya kak sotsiokul'turnyy protsess (filosofskiy aspekt). Dis. ... kand. ped. nauk. M. 2003.

5. Petrovskiy A.V., Yaroshevskiy M.G. Osnovy teoreticheskoy psikhologii. M.: INFRA-M, 1998.

6. Suslova I.B. Razvitie dukhovnoy kul'tury lichnosti sredstvami obrazovaniya. Uchebnoe posobie. Sochi. Izd-vo «Optima», 2019. 